\title{
Induction of autotetraploid Moringa plant (Moringa oleifera) using oryzalin
}

\author{
'RIDWAN, WITJAKSONO \\ Research Center for Biology, Indonesian Institute of Sciences. Jl. Raya Jakarta-Bogor Km 46, Cibinong, Bogor 19152, West Java, Indonesia. \\ Tel.: +62-21-87907604, Fax.: +62-21-87907612, •email: witjaksono1961@gmail.com; witj001@lipi.go.id
}

Manuscript received: 17 May 2020. Revision accepted: 12 August 2020.

\begin{abstract}
Ridwan, Witjaksono. 2020. Induction of autotetraploid Moringa plant (Moringa oleifera) using oryzalin. Biodiversitas 21: 4086-4093. Moringa (Moringa oleifera Lam.) is a plant with high nutritional content and has been widely used as a vegetable and health food ingredient, but its utilization and productivity have not been optimal. Increasing plant productivity can be done by increasing biomass which can be obtained through increasing plant ploidy. This study aims at obtaining tetraploid Moringa by induction using oryzalin compound. Moringa germinating seeds were soaked in oryzalin water solutions for 1, 3, and 5 days with concentrations of 0 $\mu \mathrm{M}$ (control), $15 \mu \mathrm{M}, 30 \mu \mathrm{M}, 60 \mu \mathrm{M}$, and $120 \mu \mathrm{M}$ with 10 seeds for each treatment. We have recovered two tetraploid Moringa plants and two chimeric plants of diploid and tetraploid genomes. Immersing germinating seeds for 1 day in 15 or $60 \mu \mathrm{M}$ oryzalin concentration effectively induced autopolyploid in Moringa. Tetraploid plants exhibit typical morphological characteristics of a tetraploid, such as low stomata density, larger stomata size, and larger leaflet size compared to the diploid counterpart. The induced tetraploid plants have significantly increased protein, fat, and calcium content compared to the diploid counterpart emphasizing their values as functional food. This polyploidy induction method can be used to produce Moringa tetraploid lines from various accessions in the attempts of developing and selecting high yielding tetraploid Moringa cultivars.
\end{abstract}

Keywords: Drumstick tree, germinating seeds, Moringa oleifera, oryzalin, polyploidy, tetraploid

\section{INTRODUCTION}

Moringa that is also known as horseradish tree or drumstick tree (Moringa oleifera Lam.) is a fast-growing tree up to 10-12 $\mathrm{m}$ height (Parrota 2014) of the Moringaceae family and has a diploid chromosome of 28 (Samuel et al. 2015). The leaves are compound consisted of leaflets with 1.2-2.0 cm length and $0.6-1.0 \mathrm{~cm}$ width. Moringa grows from sea level to $2000 \mathrm{~m}$ above sea level and thrives on a variety of soil types (Raja et al. 2016). Moringa originated from the foothills of the Himalayas in North India, and spread to the tropical areas of Asia, Central to South America and Africa (Parrota 2014). In Indonesia, Moringa is spread in almost all southern regions, including Java, Madura, Lesser Sunda Islands such as Bali, Lombok to Alor (Riastiwi et al. 2018).

Moringa is consumed as a vegetable in some parts of Indonesia, i.e., eastern part. Moringa leaf vegetables can be a source of protein, minerals, and carbohydrates because of their high content of $22.75 \%, 13.02 \%$, and $51.66 \%$, respectively. Dried Moringa leaf has high nutrient density, which is 7 times of the vitamin $\mathrm{C}$ of oranges, 17 times of the calcium of milk, 10 times of the vitamin A of carrots, 9 times of the protein of yogurt, 15 times of the potassium of bananas, and 25 times of the iron of spinach (Koul and Chase 2015). Its antioxidant content is relatively high, especially the one from the flavonoid group (Muhammad et al. 2016; Edwinanto et al. 2018; Lin et al. 2018), even 3 times that of other vegetables (Pakade et al. 2013). Together with its content of sterol compounds and other diverse compounds, this plant can serve also as a functional food and a medicinal plant. In addition, the seed of this plant has high protein and fat content each about 32\% (Melo et al. 2013) and has various industrial values such as feed, organic fertilizer (Parwata and Soemeinaboedhy 2018), and water purification (Bina et al. 2010; BeltranHeredia et al. 2012, Winarno 2018). Although its benefits are very broad, Moringa is commonly planted as border plants, rarely in intensive cultivations. To encourage cultivation, it is necessary to develop superior varieties with high biomass production.

Efforts to develop such varieties could be done, alternatively, by inducing polyploidy, which is increasing plant chromosome set from diploid to polyploid. Plant ploidy levels affect biomass accumulation parabolically. For example, biomass accumulation increases from diploid to tetraploid and decreases at hexaploid and continues to decrease at octoploid in Arabidopsis (Corneillie et al. 2018). In Populus, the optimum ploidi level for biomass accumulation was demonstrated to be triploid (Liqin et al 2019). However, significant increase in biomass or leaf size from diploid to tetraploid has been demonstrated in many plants. Tetraploid bananas are bigger than triploid and diploid bananas (Poerba et al. 2014). Compared to the original diploid bananas, the induced polyploid bananas also show thicker leaves, larger leaf stems, and fatter fruits as shown in the tetraploid 'Mas Lumut' (Poerba et al. 2014), tetraploid 'Mas Madu' (Poerba et al. 2019a), tetraploid 'Rejang' (Poerba et al. 2017), 'Mas Jambe' autotetraploid (Poerba et al. 2018), 'Klutuk Sukun' 
autotetraploid (Poerba et al. 2019b). Induced tetraploid teak also has leaves that are thicker than the diploid counterpart (Ridwan et al. 2018). Increased biomass due to increased ploidy has been widely reported (Ketsa et al. 2001; Ye et. al. 2010; Wang et. al. 2015).

Autopolyploidy could be induced in various ways, including treatment of shoot apices with antimitotic compounds that inhibit the formation of mitotic spindles such as oryzalin, colchicine, trifluralin (Gallone et al. 2014; Feng et al. 2017). Oryzalin has been reported to be effective in inducing polyploidy, for example in Hylocereus megalanthus (Tel-Zur et al. 2011), Allium cepa (Grzebelus and Adamus 2004), Hebe "Oratia Beauty" (Gallone et. al. 2014).

Induction of tetraploid Moringa plants by immersion of germinating seeds in oryzalin solution and characterization of morphological and nutritional traits of the resulting tetraploid plants are reported in this paper.

\section{MATERIAL AND METHODS}

Plant material was seeds collected and dried from Moringa plants grew in the garden of Research Center for Biology LIPI. The mature seeds were cleaned and their wings were removed and then soaked in sterile distilled water for 60 minutes. The seeds were then placed in Petri dishes lined with moist tissue paper until they germinated characterized by the growth of roots of $2-4 \mathrm{~cm}$ long. To induce polyploidy, the germinating seeds were then immersed in various concentrations of oryzalin at various times.

The experimental treatment consisted of 2 factors, i.e., the concentration of oryzalin $(0,15,30,60$, and $120 \mu \mathrm{M})$, and the duration of immersion (1, 3, and 5 days). As many as 10 germinating seeds were immersed in each treatment solution. As much as $200 \mathrm{~mL}$ of treatment solutions were placed in a glass bottle with a capacity of $330 \mathrm{~mL}$. The treatments were maintained in a room with temperature of $20-25^{\circ} \mathrm{C}$ with relative humidity of $60-80 \%$ and with diffuse lighting. After the treatment period, the Moringa germinating seeds were planted in $5 \times 10 \mathrm{~cm}$ plastic bag filled with growth media with composition of 2 topsoil, 1 charcoaled rice husk, and 1 compost. They were maintained under $55 \%$ shade. After 4 weeks, the seedlings were then transferred to growth medium in bigger plastic bags measuring $35 \times 45 \mathrm{~cm}$ and placed in an open field for growth observation.

Phenotypic evaluation included: (i) plant growth including plant survival, plant height, stem diameter, number of compound leaves, and leaf area of a selected compound leaf; (ii) ploidy level of the resulting plants; and (iii) stomatal density and size. The plant survival is calculated from the number of seedlings that grow at the age of 1 and 4 weeks after planting (WAP) and then presented as percentage of survival. Observations on plant height, stem diameter, and number of compound leaves were carried out for all plants at 1.5 months after transferred to open land. For the leaf area observation, the identified polyploid plants and three randomly selected control plants at 2 months after being moved to the open land were sampled. The samples were 10 leaflets taken from the $4^{\text {th }}$ compound leaf from apex. The leaflets were detached from the petioles and laid on a white paper for photographing. Photographs of the leaflets were analyzed with ImageJ $1.47 \mathrm{v}$ software to obtain leaf area.

Plant ploidy level was analyzed using CyFlow Ploidy Analyser (Partex, Germany). A sample of young leaflets measuring $1 \mathrm{~cm}^{2}$ was suspended in $250 \mu \mathrm{L}$ Cysteine PI Absolute then chopped into small pieces with a razor blade. The chopped leaflets were then filtered into a sample tube, then added with $1 \mathrm{~mL}$ of buffer solution containing Propidium Iodide and RNase) for relative DNA content reading. Leaflet samples from Moringa control plants were used as a diploid reference and their peak of relative value of DNA was set at a value of 200. Thus, the peak relative DNA content with a value of 400 indicates a tetraploid plant and the multiple peak values indicate the presence of multiple ploidy or chimera. Histograms that show peaks with values of 200 and 400 at the same time indicate chimeric plants with diploid and tetraploid chromosomes and called mixoploid. All plants grown from the treatments were sampled, while from the control treatment without oryzalin, only three plants of 1-day immersion were sampled.

Plants that had been identified as tetraploids and mixoploids were observed for their stomatal density and stomatal size and compared to diploid control to confirm ploidy. Leaflet samples were selected from the ones located at the base, middle, and upper part of each fully expanded compound leaf from every branch. The preparation for stomatal observation followed method developed by Haryanti (2010) with slight modification. Leaflet samples while still attached to the tree were smeared with transparent nail polisher (Revlon) at abaxial surface and allowed to dry. A piece of clear adhesive tape was pasted to overlay the dried smeared polisher. After a while, the tape was then removed bringing along the thin film of nail polisher with stomatal prints in it. The tape was then put on an objective glass for microscopic analysis. Observation of stomata density was done by counting the number of stomata manually with a light microscope at magnification 40 times and divided by visual field area $(0.126 \mathrm{~mm} 2)$, whereas observations of stomata size were carried out at 100 times magnification.

Proximate analyses, which comprised carbohydrate, fat, protein, calcium, and ash content were performed when the plants were 1.5 years old, with leaf samples from the 3rd to 7 th from the apex. Fresh leaves were washed thoroughly with running water and then dried in an oven at a temperature of $55^{\circ}$ for 3 days. The dried leaves were then blended to fine powder. The leaf powder was sent to a commercial laboratory (PT. Saraswanti Indo Genetech, Bogor) for the proximate analysis.

Statistical analysis was conducted with One-Way ANOVA using software SPSS for Windows version 16 at $\alpha=0.05$. Differences among means were detected with DMRT (Duncan Multiple Range Test) at $\alpha=0.05$. Additionally, some of the data were analyzed and presented as percentage, percentage increase, or means and their standard errors. The standard errors or referred to as deviations of samples (STDEV.S) were calculated with 
Microsoft Excel and presented also as bars in histograms of the means. Percentage increase in proximate analysis values was calculated based on the value of the control diploid.

\section{RESULTS AND DISCUSSION}

\section{Plant survival}

The oryzalin induction treatments affected the survival of Moringa plants (Figure 1). Increase in oryzalin concentrations decreased the survival of the plants. The effect of oryzalin concentrations seemed to interact with immersion period. At 1-day immersion, the reduction in the percentage of survival dramatically occurred only at the highest oryzalin concentration of $120 \mu \mathrm{M}$. At 3-day immersion, the percentage of survival decreased by more than $50 \%$ at the concentration of $15 \mu \mathrm{M}$, and the plants did not grow at a concentration of $60 \mu \mathrm{M}$. At 5-day immersion, the effect of oryzalin concentrations was stronger in the reduction of survival percentage and leaving only $30 \%$ surviving plants, even at the lowest concentration of oryzalin of $15 \mu \mathrm{M}$. Most of the plants that managed to survive until the age of 1 week continued to grow and survive until 4 weeks, and only a few of them died, including some plants from control without oryzalin treatment.

In addition to reducing the percentage of germinating seeds that grew, oryzalin treatments also significantly affected plant growth features (Table 1). Oryzalin treatment decreased the average plant height. In the 1-day immersion treatment, even though the average plant height was lower than the control, but the high standard error value on the average treatment value showed a high variation on the plant height. Variable growth of stem diameter also decreased with oryzalin treatment, especially in immersion period of 3 and 5-days, whereas in immersion 1-day, only at $15 \mathrm{uM}$, the stem diameter was not significantly different from control. The average value of the number of plant leaves tended to increase with an increase in the concentration of oryzalin at 1-day immersion, but decreased at longer immersion time.

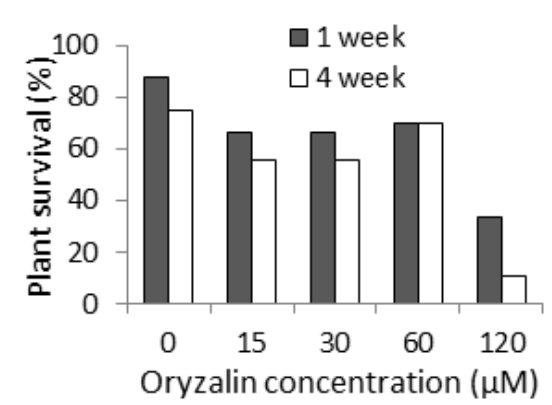

A

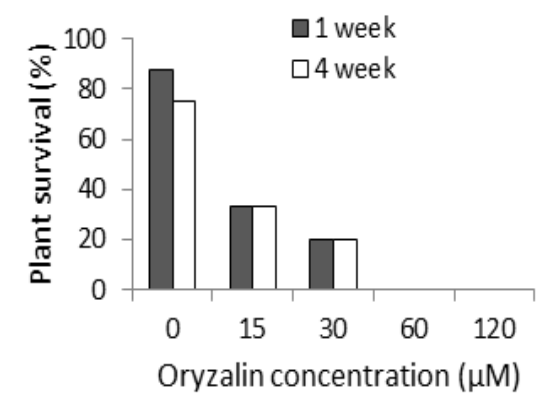

B

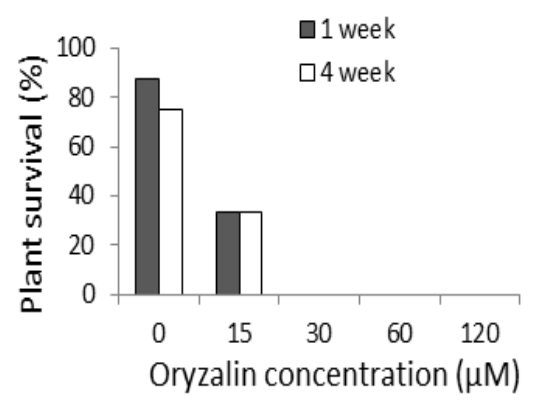

C

Figure 1. Effect of oryzalin concentrations of $0,15,30,60$, and $120 \mu \mathrm{M}$ and immersion period of 1 day (A), 3 days (B), and 5 days (C) on plant survival percentage at 1 and 4 weeks after planting in an open field

Table 1. The effect of concentrations and immersion periods of germinating seeds in oryzalin solution on subsequent plant growth parameters 75 days after planting

\begin{tabular}{|c|c|c|c|c|}
\hline \multicolumn{2}{|c|}{ Oryzalin treatments } & \multicolumn{3}{|c|}{ Growth parameters } \\
\hline $\begin{array}{c}\text { Concentration } \\
(\mu \mathrm{M})\end{array}$ & $\begin{array}{c}\text { Immersion period } \\
\text { (days) }\end{array}$ & Height (cm) & Stem diameter $(\mathbf{m m})$ & $\begin{array}{c}\text { Leaf number } \\
\text { (unit) }\end{array}$ \\
\hline 0 & 1 & $58.50 \pm 1.29 \mathrm{a}$ & $12.13 \pm 0.76 \mathrm{a}$ & $8.75 \pm 0.50 \mathrm{ab}$ \\
\hline 15 & 1 & $48.2 \pm 8.81 \mathrm{ab}$ & $11.24 \pm 1.69 \mathrm{abc}$ & $12.00 \pm 3.46 \mathrm{ab}$ \\
\hline 30 & 1 & $38.25 \pm 7.14 b$ & $8.30 \pm 0.67 \mathrm{~d}$ & $12.50 \pm 3.87 \mathrm{ab}$ \\
\hline 60 & 1 & $42.83 \pm 11.86 \mathrm{ab}$ & $9.27 \pm 1.97 \mathrm{bcd}$ & $11.17 \pm 3.25 \mathrm{ab}$ \\
\hline 120 & 1 & $44.00 \pm 0.00 \mathrm{ab}$ & $10.00 \pm 0.00 \mathrm{abcd}$ & $8.00 \pm 0.00 \mathrm{~b}$ \\
\hline 0 & 3 & $57.40 \pm 14.08 \mathrm{a}$ & $12.26 \pm 1.66 \mathrm{a}$ & $13.60 \pm 3.05 \mathrm{a}$ \\
\hline 15 & 3 & $34.00 \pm 0.00 \mathrm{~b}$ & $9.40 \pm 0.00 \mathrm{bcd}$ & $8.00 \pm 0.00 \mathrm{~b}$ \\
\hline 30 & 3 & $44.00 \pm 0.00 \mathrm{ab}$ & $8.6 \pm 0.00 \mathrm{~d}$ & $8.00 \pm 0.00 \mathrm{~b}$ \\
\hline 60 & 3 & \multicolumn{3}{|c|}{$\ldots \ldots \ldots \ldots \ldots$ no growth $\ldots \ldots \ldots \ldots$} \\
\hline 120 & 3 & \multicolumn{3}{|c|}{$\ldots \ldots \ldots \ldots \ldots$ no growth. . . . . . . . } \\
\hline 0 & 5 & $59.33 \pm 7.53 \mathrm{a}$ & $11.38 \pm 0.88 \mathrm{ab}$ & $12.83 \pm 1.47 \mathrm{a}$ \\
\hline 15 & 5 & $49.00 \pm 1.41 \mathrm{ab}$ & $8.90 \pm 0.85 \mathrm{~cd}$ & $10.00 \pm 1.41 \mathrm{ab}$ \\
\hline 30 & 5 & & . . no growth. ... . & \\
\hline 60 & 5 & & ... no growth. . & \\
\hline 120 & 5 & $\ldots \ldots$ & $\ldots$ no growth. ...... & \\
\hline
\end{tabular}

Note: Data are presented as means \pm standard error. Numbers in the same column followed by different letters are significant differences at $\mathrm{p} \leq 0.05$ DMRT 

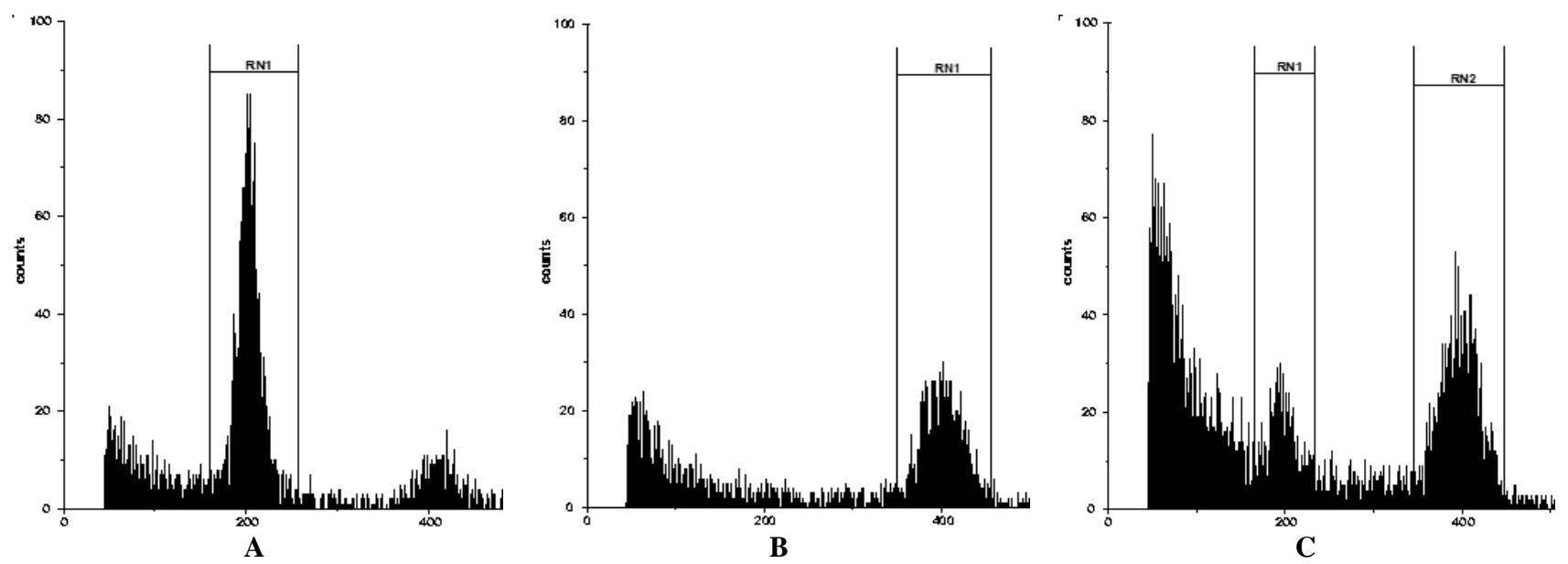

Figure 2. Graphs of flow cytometry analysis show peaks of control diploid Moringa plant and the treated plants indicating polyploidy. Peak of control diploid was set at channel 200 (A), peak at channel 400 (B) indicating a tetraploid plant and double peaks at channel 200 and $400(\mathrm{C})$ indicating a mixoploid plant

Table 2. The effect of germinating seed treatment of concentration and immersion period in oryzalin solution on subsequent recovery of polyploid plant according to flow cytometer analysis, 2 months after planting

\begin{tabular}{ccccc}
\hline $\begin{array}{c}\text { Oryzalin } \\
\text { concentration } \\
(\boldsymbol{\mu M})\end{array}$ & $\begin{array}{c}\text { Immersion } \\
\text { period } \\
\text { (days) }\end{array}$ & $\begin{array}{c}\text { Number of } \\
\text { plants }\end{array}$ & \multicolumn{2}{c}{ Polyploid number } \\
\cline { 4 - 5 } & 1 & 3 & 0 & 0 \\
\hline 0 & 1 & 5 & 2 & 1 \\
15 & 1 & 5 & 0 & 0 \\
30 & 1 & 7 & 0 & 1 \\
60 & 1 & 1 & 0 & 0 \\
120 & 3 & 3 & 0 & 0 \\
15 & 3 & 2 & 0 & 0 \\
30 & 5 & 3 & 0 & 0 \\
15 & 5 & & & \\
\hline
\end{tabular}

\section{Ploidy analysis}

The results of the flow cytometry analysis showed that the Moringa plants recovered from oryzalin treatment with various concentrations and duration of immersion could be grouped in 3 ploidy categories, i.e., diploid, mixoploid, and tetraploid. The plants from the control treatment were assumed to be diploid and their relative DNA contents were set at a peak of 200 (RN1) (Figure 2.A), while the tetraploid showed a peak value of $400(\mathrm{RN} 2)$ as twice the diploid value (Figure 2.B), and mixoploid had both peaks, the peak at a value of 200 indicating diploid, and the peak at a value of 400 indicating tetraploid (Figure 2.C).

Flow cytometry analysis on Moringa plants recovered from the treatments of immersing germinating seeds for 1 day at a concentration of $15 \mu \mathrm{M}$ resulted in $60 \%$ ploidy induction consisting of $40 \%$ mixoploid and $20 \%$ tetraploid. A tetraploid plant was also recovered with the same immersion duration treatment, but at a concentration of 60 $\mu \mathrm{M}$. No polyploidy induction was obtained from other treatments (Table 2).

\section{Stomatal density and size}

The stomatal density of the diploid control Moringa plants reached more than $300 \mathrm{~mm}^{-2}$ uniformly in all the sampled branches, whereas the tetraploid plants had stomatal density only around $200 \mathrm{~mm}^{-2}$ and were evenly distributed in the 2-4 branches observed (Figure 3). However, in mixoploid plants, the density of stomata varied between branches with low density similar to the density of tetraploid plants, and branches with high density similar to diploid plants. Therefore, ploidy differences in mixoploid plants occurred in different branches.

Measurement of stomatal length and width confirmed that tetraploid plants had stomatal length and width that were significantly longer than those of diploid plants, whereas mixoploid plants showed stomatal length and width between the two ploidies (Figure 4).

\section{Leaf area}

The area of leaflets increased significantly with increase in plant ploidy with an increment of about 300\% from diploid counterpart to tetraploids. However, leaf area variations occurred in mixoploid plants, both of which were characterized by big standard error. Leaf area of one of the mixoploids, number 15.1.1, was not significantly different from that of the diploid plants, but with greater variation in data. This showed that number 15.1.1 had more variability in leaf area than the diploid counterpart. Mixoploid plant of 15.1.2 showed a high diversity of leaflet areas with significantly higher values than other mixoploids and similar to leaf area of the tetraploid plants (Figure 5).

\section{Nutrient content}

Proximate analysis of diploid and the recovered polyploid plants showed differences in percent carbohydrate, protein, fat, ash, and calcium content (Table $3)$. Increased in ploidy increased leaf protein levels up to $20 \%$, but decreased carbohydrate levels by $12 \%$. The 
increase in leaf protein content in tetraploid plants seemed to be offsetted by a decrease in carbohydrate content. This symptom was evident in a mixoploid plant of 15.1.1 which showed an increase in protein of up to $11 \%$ but was also compensated by a decrease in carbohydrates by $11 \%$. Fat content also increased with an increase in ploidy, even up to $34 \%$ in a mixoploid, except in 1 tetraploid genotype whose increases were not significantly different. Ash content in one of the tetraploid genotypes of 60.1 .4 significantly increased by $20 \%$ compared to diploid control. This increase was also shown by an increase in leaf calcium levels significantly as well. The proximate value of mixoploid plants tended to resemble the proximate value of tetraploid plants more than diploid plants, except for the calcium content of one mixoploid plant which was lower than the diploid plants.

\section{Discussion}

Solid tetraploid Moringa plants have been recovered by immersing germinating seeds in oryzalin solution for 1 day with a concentration of 15 and $60 \mu \mathrm{M}$ along with mixoploid plants and diploids. Induction of tetraploid Moringa shoots in tissue culture using colchicine has been reported in an abstract with no detailed information (Zhang et al. 2007). Polyploidy induction with shoot tissue often produced mixoploid and therefore requires chimera separation, for example through repeated subcultures up to 3-5 passages to obtain intact polyploid plants, such as in bananas (Van Duren et al. 1996, Poerba et al. 2014, 2017, 2018, 2019a, 2019b). Efficient use of germinating seeds as target tissue for polyploidy induction without too much effort to separate chimera has also been demonstrated in oil palm (Madon et al. 2005), Watsonia species from South Africa (Thompson et al. 2010), Phlox drummondii (Tiwari and Mishra 2012), Rhodomyrtus tomentosa (Normasiwi and Nurlaeni 2014), water spinach Ipomea aquatica (Rahmi et al. 2019), and Lilium rosthornii plant (Wang et al. 2020).

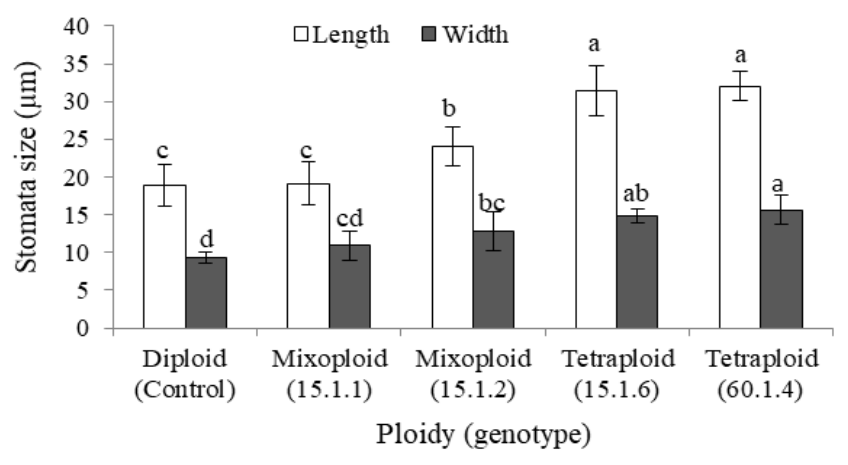

Figure 4. Comparison of the average length and width of the stomata of the diploid control Moringa, mixoploid plants of 15.1.1 and 15.1.2, and tetraploid of 15.1.6 and 60.1.4. Different letters indicate significant differences at $\leq 0.05$ DMRT

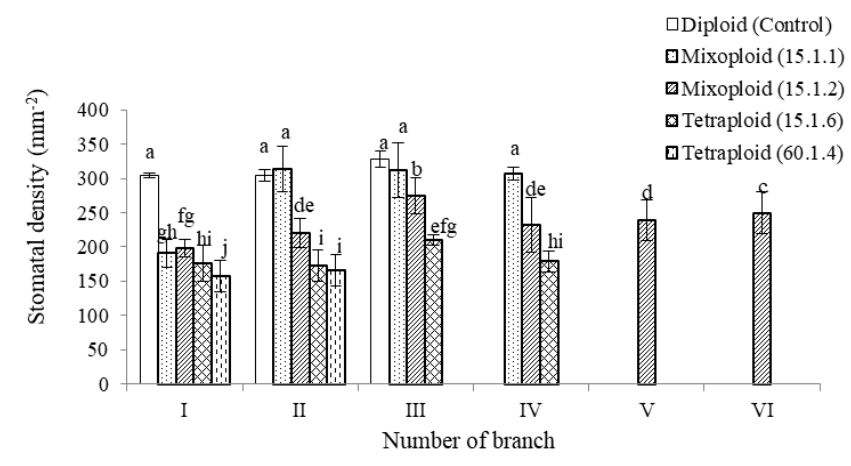

Figure 3. Comparison of the average of the stomatal density of leaflets grew from different branches of the diploid control Moringa, mixoploid plants of 15.1.1 and 15.1.2, and tetraploids of 15.1.6 and 60.1.4. Different letters indicate significant differences at $\leq 0.05$ DMRT.

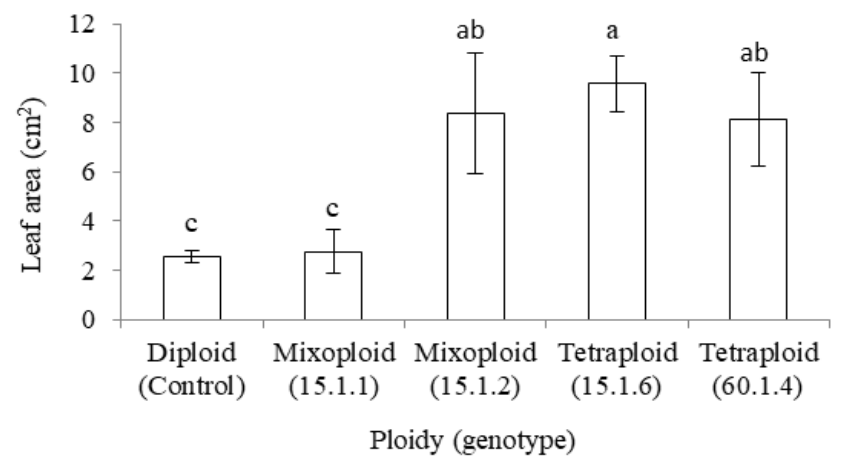

Figure 5. Comparison of leaflet area of diploid, mixoploid, and tetraploid Moringa plants. Different letters indicate significant differences at $\leq 0.05$ DMRT

Table 3. Proximate analysis of Moringa leaf of control diploid plants, and the induced polyploidy plants

\begin{tabular}{|c|c|c|c|c|c|c|c|c|c|c|}
\hline \multirow[b]{2}{*}{ Genotype (ploidy) } & \multicolumn{2}{|c|}{ Carbohydrate } & \multicolumn{2}{|c|}{ Protein } & \multicolumn{2}{|c|}{ Total fat } & \multicolumn{2}{|c|}{ Ash } & \multicolumn{2}{|c|}{ Calcium } \\
\hline & $\begin{array}{c}\text { Content } \\
(\%)\end{array}$ & $\begin{array}{c}\text { Increase } \\
(\%)\end{array}$ & $\begin{array}{c}\text { Content } \\
(\%)\end{array}$ & $\begin{array}{c}\text { Increase } \\
(\%)\end{array}$ & $\begin{array}{c}\text { Content } \\
(\%)\end{array}$ & $\begin{array}{c}\text { Increase } \\
(\%)\end{array}$ & $\begin{array}{c}\text { Content } \\
(\%)\end{array}$ & $\begin{array}{c}\text { Increase } \\
(\%)\end{array}$ & $\begin{array}{c}\text { Content } \\
(\mathrm{mg} / 100 \mathrm{~g})\end{array}$ & $\begin{array}{c}\text { Increase } \\
(\%)\end{array}$ \\
\hline Control (diploid) & $51.9 \pm 0.4 \mathrm{a}$ & & $27.1 \pm 0.2 \mathrm{~b}$ & & $5.7 \pm 0.2 \mathrm{a}$ & & $8.1 \pm 0.4 \mathrm{~b}$ & & $1833.8 \pm 380.0 \mathrm{a}$ & \\
\hline 15.1.1 (mixoploid) & $46.2 \pm 1.0 \mathrm{~b}$ & -11 & $30.0 \pm 1.0 \mathrm{ab}$ & 11 & $7.6 \pm 0.5 \mathrm{a}$ & 34 & $9.6 \pm 0.3 \mathrm{a}$ & 19 & $2203.8 \pm 42.4 \mathrm{a}$ & 20 \\
\hline 15.1.2 (mixoploid & $43.1 \pm 2.4 \mathrm{~b}$ & -17 & $33.3 \pm 1.7 \mathrm{a}$ & 23 & $7.1 \pm 0.4 \mathrm{a}$ & 25 & $9.0 \pm 0.3 \mathrm{ab}$ & 12 & $1776.6 \pm 211.4 \mathrm{a}$ & -3 \\
\hline 15.1.6 (tetraploid) & $45.6 \pm 1.8 \mathrm{~b}$ & -12 & $32.8 \pm 1.5 \mathrm{a}$ & 21 & $6.8 \pm 0.3 \mathrm{a}$ & 20 & $9.0 \pm 0.2 \mathrm{ab}$ & 12 & $1967.5 \pm 182.9 \mathrm{a}$ & 7 \\
\hline 60.1 .4 (tetraploid) & $45.6 \pm 1.5 \mathrm{~b}$ & -12 & $31.3 \pm 1.7 \mathrm{ab}$ & 16 & $6.5 \pm 0.7 \mathrm{a}$ & 13 & $9.6 \pm 0.8 \mathrm{a}$ & 19 & $2412.8 \pm 122.7 \mathrm{a}$ & 31 \\
\hline
\end{tabular}

Data are presented as mean and standard error. Numbers followed by different letters are significantly different at $\leq 0.05$ DMRT. Percentage increases were calculated based on the value of the control diploid. 
Moringa germinating seeds did not tolerate immersion duration of 3-5 days, especially at the concentration of oryzalin more than $30-60 \mu \mathrm{M}$. Determination of the duration and dose of exposure to the compounds inhibiting the formation of microtubule compounds is the key to the success of polyploidy induction. The optimal soaking time in oryzalin solution differs with different concentrations, but ranges from one day for Lilium rosthornii with a concentration of $0.01 \%(34.6 \mu \mathrm{M})$ (Wang et al. 2020), two days for Hylocereus megalanthus with a concentration of $0.0005 \%(0.7 \mu \mathrm{M})($ Tel-Zur et al. 2011) and Hebe "Oratia Beauty" with a concentration of $289 \mu \mathrm{M}$ (Gallone et. al. 2014), three days for Allium cepa plants with a concentration of $50 \mu \mathrm{M}$ (Grzebelus and Adamus 2004).

The effective concentration of oryzalin of $15 \mu \mathrm{M}$ for the induction Moringa autotetraploid is considered a low concentration. Oryzalin is used for induction of polyploidy with very wide concentration range depending on the target plant species, from a very low one at $0.7 \mathrm{uM}$ for Hylocereus megalanthus (Tel-Zur et al. 2011) to the highest at a concentration of $289 \mu \mathrm{M}$ for hebe 'Oratia plants Beauty' (Gallone et al. 2014). In most plants, the concentration of oryzalin at tens of micromolar intervals proved effective for the induction of polyploidy, for example in Aframomum corrorima plants at a concentration of $10 \mu \mathrm{M}$ (Wannakrairoj \& Tefera 2013), Lychnis spp. at a concentration of $10 \mathrm{mg} \mathrm{L}^{-1}(28.9 \mu \mathrm{M})$ (Nonaka et al. 2011), cayenne pepper at a concentration of 10-30 $\mathrm{mg} \mathrm{L}^{-1}$ (28.9-86.6 $\left.\mu \mathrm{M}\right)$ (Pliankong et al. 2017), orchid plants at a concentration of $57,7 \mu \mathrm{M}$ (Miguel and Leonhardt 2011), on bananas at a concentration of 15-60 $\mu$ M (Van Duren et al. 1996; Poerba et al. 2014, 2017, 2018, 2019a, 2019b).

Induced tetraploid Moringa plants show morphological characteristics that are typical of tetraploid and are different from diploid plants, which among others have lower stomatal density but larger stomata size. These characters are in accordance with the results of tetraploid induction experiments on water spinach (Rahmi et al. 2019), teak (Ridwan et al. 2018), bananas (Poerba et al. 2014, 2017, 2018, 2019a, 2019b). These properties could be used to identify polyploid plants in many plants when flow cytometers are not available, for example in cotton plants (Wongpiasatid et al. 2005), some plants of the Orchidaceae such as the orchid Dendrobium, Epidendrum, Odontioda, and Phalaenopsis (Miguel and Leonhardt 2011), cactus (Tel-Zur et al. 2011), Phlox drummondii (Tiwari and Mishra 2012), and cayenne pepper plants (Pliankong et al. 2017).

Tetraploid Moringa plants obtained showed a larger leaf size than diploid plants. The size of the vegetative part of polyploid plants which is larger than diploid origin has been shown in various plants, including Swainsona formosa (Zulkarnain 2004), crape myrtle flowers (Ye et al. 2010), bananas (Poerba et al. 2014, 2017,2018, 2019a, 2019b), pear (Wang et al. 2015), daylily (Podwyszynska et al. 2015) and teak seedlings (Ridwan et al. 2018). For this reason, the tetraploid induction in Moringa is intended to increase biomass which ultimately increases its productivity. This evidence has not been obtained until the tetraploid Moringa plants can be propagated in sufficient quantities and tested agronomically. However, proximate analysis demonstrated that tetraploid plants have higher levels of protein, fat, and minerals than diploid plants indicates the potential of induced tetraploid Moringa plants as functional food. Moringa has been traded as flour and is used as a mixture for making noodles, cakes, and even cosmetic products. Moringa leaf flour with higher protein, fat and mineral content could be an alternative solution for national nutritional problems such as stunting caused by undernourishment (Uauy et al. 2015; Sari et al. 2016; Sulistiani and Yanti 2016).

The conclusion is that induction of polyploidy in Moringa plant could be done by immersing germinating seeds with $2-4 \mathrm{~cm}$ roots in $15-60 \mu \mathrm{M}$ oryzalin solutions for one day. A total of two tetraploid plants and two mixoploid plants have been recovered in accordance with the results of the flow cytometer analysis confirmed with low stomatal density and large stomatal size. Tetraploid plants exhibit typical polyploid characteristics, i.e., larger leaflets than the original diploid plant. Tetraploid plants also show increased levels of protein, fat, and minerals but decreased carbohydrate levels. These characteristics conform to functional food criteria and could be used as an alternative to mitigate one of the national nutritional problems such as stunting. The effectiveness of the polyploidy induction described in this paper could be recommended as a method to produce tetraploid Moringa lines from many seeds from various varieties or genotypes. With selections and agronomic evaluations, it is expected that superior tetraploid Moringa cultivars with high productivities and nutritional contents could be developed.

\section{ACKNOWLEDGEMENTS}

We would like to appreciate Elin and Ujang Hafid for their technical assistance during this research. This research was funded by DIPA Research Center for Biology, LIPI Fiscal Year of 2017. *Both authors are major contributors to this work.

\section{REFERENCES}

Beltran-Heredia J, Sanchez-Martin J, Barrado-Moreno M. 2012. Longchain anionic surfactants in aqueous solution. Removal by Moringa oleifera coagulant. Chem En J 180: 128-136. DOI: 10.1016/j.cej.2011.11.024.

Bina B, Mehdinejad MH, Dalhammer G, Rajarao G, Nikaeen M, Attar HM. 2010. Effectiveness of Moringa oleifera coagulant protein as natural coagulant aid in removal of turbidity and bacteria from turbid waters. Int. J Environ Eco Eng 4 (7): 261-263. DOI: 10.5281/zenodo.1060399.

Corneillie S, De Storme N, Van Acker R, Fangel JU, De Bruyne M, De Rycke RM, Geelen DNV, Willats WGT, Vanholme B, Boerjan WA. 2018. Polyploidy affects plant growth and alters cell wall composition. Plant Physiol 179 (1): 74-87 10.1104/pp.18.00967

Edwinanto L, Septiadi E, Nurfazriah LR, Anastasya KS, Pranata P. 2018. Phytochemical Features of Moringa oleifera leaves as anticancer. A review article. Journal of Medicine and Health 2 (1): 680-688. DOI: 10.28932/jmh.v2i1.745 
Feng H, Wang ML, Cong RC, Dai SL. 2017. Colchicine and trifluralinmediated polyploidization of Rosa multiflora Thunb. var. inermis and Rosa roxburghii f. normalis. J Hort Sci Biotech 92: (3) 279-287. DOI: 10.1080/14620316.2016.1249964

Gallone A, Hunter A, Douglas GC. 2014. Polyploid induction in vitro using colchicine and oryzalin on Hebe 'Oratia Beauty': Production and characterization of the vegetative traits. Scientia Horticulturae. 179: 59-66. DOI: 10.1016/j.scienta.2014.09.014.

Grzebelus E, Adamus A. 2004. Effect of anti-mitotic agents on development and genome doubling of gynogenetic onion (Allium cepa L.) embryos. Plant Science 167: 569-574. DOI: 10.1016/j.plantsci.2004.05.001.

Haryanti S. 2010. Jumlah dan distribusi stomata pada daun beberapa spesies tanaman dikotil dan monokotil. Buletin Anatomi dan Fisiologi XVIII (2): 21-28. DOI: 10.14710/baf.v18i2.2600. [Indonesian]

Ketsa S, Uthairatanakij A, Prayurawong A. 2001. Senescence of diploid and tetraploid cut inflorescences of Dendrobium 'Caesar'. Scientia Horticulturae 91: 133-141. DOI: 10.1016/S0304-4238(01)00248-5.

Koul B, Chase N. 2015. Moringa oleifera Lam.: Panacea to several maladies. J Chem Pharm Res 7(6): 687-707. www.jocpr.com

Lin M, Zhang J, Chen X. 2018. Bioactive flavonoids in Moringa oleifera and their health-promoting properties. Journal of Functional Food 47: 469-479. DOI: 10.1016/j.jff.2018.06.011.

Liqin G, Jianguo Z, Xiaoxia L, R. Guodong. 2019. Polyploidy-related differential gene expression between diploid and synthesized allotriploid and allotetraploid hybrids of Populus. Mol Breeding 39 (5): 69. DOI: 10.1007/s1 1032-019-0975-6

Madon M, Clyde MM, Hashim H, Yusuf YM, Mat H, Saratha S. 2005. Polyploidy induction of oil palm through colchicine and oryzalin treatments. J. Oil Palm Res. 17: 110-123.

Melo V, Vargas N, Quirino T, Calvo CMC. 2013. Moringa oleifera L. An underutilized tree with macronutrients for human health. J Food Agric 25 (10): 785-789. DOI: 10.9755/ejfa.v25i10.17003.

Miguel TP, Leonhardt KW. 2011. In vitro polyploid induction of orchids using oryzalin. Sci Hort 130: 314-319. DOI 10.1016/j.scienta.2011.07.002

Muhammad HI, Asmawi MZ, Khan NAK. 2016. A review on promising phytochemical, nutritional and glycemic control studies on Moringa oleifera Lam. in tropical and sub-tropical regions. Asian Pac J Trop Biomed 6 (10): 896-902. DOI: 10.1016/j.apjtb.2016.08.006.

Nonaka T, Oka E, Asano M, Kuwayama S, Tasaki H, Han DS, Godo T, Nakano M. 2011. Chromosome doubling of Lychnis spp. by in vitro spindle toxin treatment of nodal segments. Scie Hort 129: 832-839. DOI: 10.1016/j.scienta.2011.05.004.

Normasiwi S, Nurlaeni Y. 2014. Induksi poliploidi tumbuhan Rhodomytrus tomentosa (Aiton) Hassk. asal gunung tandikat Sumatera Barat menggunakan orizalin. Prosiding Seminar Nasional Hasil Penelitian Unggualn Bidang Pangan Nabati. Bogor. [Indonesian]

Pakade V, Chimuka L, Cukrowska. 2013. Comparison of antioxidant activity of Moringa oleifera and selected vegetables in South Africa. South Afr J Scie 109: 1-5. DOI: 10.1590/sajs.2013/1154

Parrota JA. 2014. Moringa oleifera. Enzyklopädie der Holzgewächse. In Roloff A, Weisgerber H, Lang U, Stimm B. (eds.) Handbuch und Atlas der Dendrologie. Wiley, Weinheim. DOI 10.1002/9783527678518.ehg2005015.

Parwata IGMA, Soemeinaboedhy INy. 2018. Pengenalan teknologi produksi biomassa intensif tanam kelor (Moringa oleifera Lam.) sebagai sumber pangan-herbal sehat di kawasan amor-amor, Desa Gumantar, Kabupaten Lombok Utara. Prosiding PKM-CSR, Vol.1. eISSN: 2655-3570.

Pliankong P, Suksa-Ard P, Wannakrairoj S. 2017. Effects of colchicine and oryzalin on polyploidy induction and production of capsaicin in Capsicum frutescens L. Thai Agric Sci 50 (2): 108-120.

Poerba YS, Witjaksono, Ahmad F, Handayani T. 2014. Induksi dan karakterisasi pisang Mas Lumut tetraploid. Jurnal Biologi Indonesia 10 (2): 191-200. [Indonesian]

Poerba YS, Handayani T, Witjaksono. 2017. Karakterisasi Pisang Rejang Tetraploid hasil induksi dengan Oryzalin. Berita Biologi 16 (1): 8593. [Indonesian]

Poerba YS, Martanti D, Handayani T, Witjaksono. 2018. Induction and Characterization of Autotetraploid Mas Jambe Banana Using Oryzalin Treatment. The 8th Annual Basic Science International Conference. AIP Conference Proceedings 2021, 070019 (2018). DOI: 10.1063/1.5062817.
Poerba Y.S, Martanti D, Handayani T, Witjaksono. 2019a. Morphology and reproductive function of induced autotetraploid banana by chromosome doubling. SABRAO Journal of Breeding and Genetics 51 (2): 175-190.

Poerba YS, Martanti D, Handayani T, Witjaksono. 2019b. Induction of banana autotetraploid "Klutuk Sukun" and their reproductive function for producing triploid hybrids. Asian Journal of Plant Science 18: 91100. DOI: 10.3923/ajps.2019.91.100.

Rahmi P, Witjaksono, Ratnadewi D. 2019. Induksi poliploidi tanaman kangkung (Ipomea aquatica Forssk.) kultivar "Salina" in vitro dengan oryzalin. Jurnal Biolpgi Indonesia 15 (1): 1-8. [Indonesian]

Raja RR, Sreenivasulu M, Vaishavi S, Navyasri DM, Samatha G, Geethalakshmi S. 2016. Moringa oleifera-an overview. RA J Appl Res 2 (09): 620-624. DOI: 10.18535/rajar/v2i9.05.

Riastiwi I, Damayanto IPGP, Ridwan, Handayani T, Leksonowati A. 2018. Moringa oleifera distribution in Java and Lesser Sunda Islands attributed with annual rainfall. Biosaintifika. 10 (3): 613-621. DOI: 10.15294/biosaintifika.v10i3.16115.

Ridwan, Handayani T, Riastiwi I, Witjaksono. 2018. Bibit jati tetraploid lebih toleran terhadap cekaman kekeringan daripada bibit jati diploid asalnya. Bibit jati tetraploid lebih toleran terhadap cekaman kekeringan daripada bibit jati diploid asalnya 7 (1): 1-11. DOI: 10.18330/jwallacea.2018.vol7iss1pp1-11. [Indonesian]

Samuel SA, Francis AO, Onyinyechi UO, Ayomide O. 2015. Effects of moringa oleifera leaf extract on red and white blood cells counts. Int $\mathbf{J}$ Curr Med Pharm Res 1 (9): 150-161.

Sari EM, Juffrie M, Nurani N, Sitaresmi MN. 2016. Asupan protein, kalsium dan fosfor pada anak stunting dan tidak stunting usia 24-59 bulan. Jurnal Gizi Klinik Indonesia 12 (4): 152-159. DOI: 10.22146/ijcn.23111 [Indonesian]

Sulistiani A, Yanti DAM. 2016. Kurangnya asupan makanan sebagai penyebab kejadian balita pendek (stunting). Jurnal Dunia Kesehatan. 5 (1): 71-75. [Indonesian]

Tel-Zur N, Dudai M, Raveh E, Mizrahi Y. 2011. In situ induction of chromosome doubling in vine cacti (Cactaceae). Scientia Horticulturae 129: 570-576. DOI: 10.1016/j.scienta.2011.04.027.

Thompson DI, Anderson NO, Staden JV. 2010. Colchicine-induced somatic polyploids from in vitro-germinated seeds of South African Watsonia species. HortScience. 45 (9): 1398-1402. DOI: 10.21273/HORTSCI.45.9.1398.

Tiwari AK, Mishra SK. 2012. Effect of colchicine on mitotic polyploidization and morphological characteristics of Phlox drummondi. African J Biotech 11 (39): 9336-9342. DOI: 10.5897/AJB11.2196

Uauy R, Kurbad A, Tano-Deerah K, Otoo GE, Aaron GA, Toride Y, Ghosh S. 2015. Role of protein and amino acids in infant and young child nutrition: Protein and amino acid needs and relationship with child growth. J Nutr Sci Vitaminol 61: 192-194. DOI: 10.3177/jnsv.61.S192.

van Duren M, Morpurgo R, Dolezel J, Afza R. 1996. Induction and verification of autotetraploids in diploid banana (Musa acuminata) by in vitro techniques. Euphytica 88: 25-34. DOI: 10.1007/BF00029262.

Wang X, Wang H, Shi C, Zhang X, Duan K, Luo J. 2015. Morphological, cytological and fertility of a spontaneous tetraploid of the diploid pear (Pyrus pyrifolia Nakai) cultivar 'cuiguan'. Scientia Horticulturae 189: 59-65. DOI: $10.1016 /$ j.scienta.2015.03.048

Wang LJ, Zhang Q, Chao QZ, Gao X, Jia GX. 2020. An efficient method for inducing multiple genotypes of tetraploids Lilium rosthornii Diels. Plant Cell Tiss Organ Cult 141: 499-510. DOI: 10.1007/s11240-02001807-4.

Wannakrairoj S, Tefera W. 2013. In Vitro chromosome doubling in Korarima [Aframomum corrorima (Braun) P.C.M. Jansen] using colchicine and oryzalin. Kasetsart J 47: 684-694.

Winarno. 2018. Tanaman Kelor (Moringa oleifera) Nilai Gizi, Manfaat, dan Potensi Usaha. PT. Gramedia Pustaka Utama. Jakarta, Indonesia. [Indonesian]

Wongpiasatid A, Hormchan P, Chusreeaeom K, Ratanadilok Ng. 2005. Stomatal size, stomatal frequency and pollen grain diameter as indirect method for identification of ploidy levels in cotton. Kasetsart J 39: 552-559.

Ye YM, Tong J, Shi XP, Yuan W, and Li GR. 2010. Morphological and cytological studies of diploid and colchicine-induced tetraploid lines of crape myrtle (Lagerstroemia indica L.). Sci Hort 124 (1): 95-101. DOI: 10.1016/j.scienta.2009.12.016. 
Zhang Jie, He Lin, Wang Li-Chao, Liang Guo-Lu. 2007. Colchicines to Induce polyploid on Moringa oleifera in Tissue Culture. Tropical Agricultural Science \& Technology (abstract). http: //en.cnki.com.cn/Article_en/CJFDTOTAL-YNRJ200701009.htm
Zulkarnain. 2004. Comparison of diploid Swainsona formosa and their tetraploid relatives obtained from oryzalin treatment. Hayati 11 (1): 610 . 